\title{
Model for determining subjective and objective factors of tax evasion $^{1}$
}

\section{Model determinacije subjektivnih i objektivnih faktora porezne evazije}

\begin{abstract}
Tax evasion is affected by many diverse subjective and objective factors. They are intertwined and determined as well as mutually connected and complementary. This paper is aimed at and orientated towards identifying the factors, both subjective and objective, that affect tax evasion in Bosnia and Herzegovina. The main research result indicates that tax evasion has multiplicative effects. It destroys the reputation of institutions primarily and, in particular, the reputation of the tax administration, it poses a threat to the tax system and rule of law, causing taxpayers distrust of the tax system itself. Thus, by reducing tax evasion the situation in public finances improves substantially. The paper shows the theoretical analysis of the phenomenon of tax evasion (which is not a goal in itself), including the empirical analysis of the subjective and objective factors that have the greatest influence on tax evasion in Bosnia and Herzegovina and the assessment of the amount of taxes evaded.
\end{abstract}

Keywords: tax, tax evasion, tax system, tax administration, tax burden and tax rate, corruption

JEL classification: $\mathrm{H} 20, \mathrm{H} 26, \mathrm{H} 32, \mathrm{C} 12$

\section{Sažetak}

Na poreznu evaziju utječu svojom isprepletenošću i determiniranošću brojni subjektivni i objektivni čimbenici, a svi čimbenici porezne evazije su uzajamno povezani i nadopunjujući. Cilj i svrha ovog rada je identifikacija subjektivnih i objektivnih čimbenika, koji utječu na poreznu evaziju u Bosni i Hercegovini. Osnovni rezultat istraživanja ukazuje da porezna evazija ima multiplikativno djelovanje, narušava ugled, prije svega institucija, posebno porezne administracije, ugrožava porezni sustav i načela pravne države, uzrokujući nepovjerenje, prije svega poreznih obveznika u sam porezni sustav te se smanjenjem porezne evazije, značajno poboljšava stanje u javnim financijama. U radu je prikazana teorijska analiza fenomena porezne evazije (koja nije sama sebi cilj), s empirijskom analizom subjektivnih i objektivnih čimbenika koji najviše utječu na poreznu evaziju u Bosni i Hercegovini, s procjenom visine porezne evazije.

Ključne riječi: porez, porezna evazija, porezni sustav, porezna administracija, porezno opterećenje i porezna stopa, korupcija

JEL klasifikacija: H2O, H26, H32, C12
1 This work is based on the research conducted by Faculty of Economics at the University of Banja Luka, Bosnia and Herzegovina for a doctoral thesis „Model for determination of subjective and objective tax evasion factors" by intrant Saudin Terzic, under the mentorship of full-time professor PhD Aleksandar Stojanović.
Saudin Terzić, MSc

Indirect Taxation Authority of Bosnia and Herzegovina

E-mail: saudin.terzic@gmail.com

\section{Mr.sc. Saudin Terzić}

Uprava za neizravno oporezivanje Bosne i Hercegovine

E-mail: saudin.terzic@gmail.com 
Terzić, S.

Model for determining subjective and objective factors of tax evasion

\section{Introduction}

Modern business is characterized by numerous, big and turbulent changes, increasing liberalization and globalization, increased taxpayer mobility, growth and accelerated development of regulatory standards, and in this domain the issue of tax evasion gains a special dimension and becomes very important, not only for tax authorities that are implementing tax regulations, but also for taxpayers themselves. Tax evasion involves our everyday life (Ruso, 2010, p.3.). Is tax evasion a hot topic in economics and social sciences (Kirchler, 2009, p.1)? Based on the search of the term "tax evasion" at the specialist academic search engine google scholar, 143,000 articles were found (the search was conducted in November 2016). The functioning of the tax system and taxation in one economy is of crucial importance to the overall financial stability, and tax evasion is one of the major risks if not addressed adequately and, depending on the amount of taxes evaded, can trigger severe financial instability in a country. For that purpose, the issue of tax evasion is raised and nowadays it constitutes one of the most complex but also very important tax issues in the functioning of national institutions. The tax system in a modern state is the central pillar of the overall financial system and, without it functioning properly, no efficient economic policy can be implemented.

Basically, tax evasion is a very important element of the tax system because it is inextricably linked to taxation. To a greater or lesser extent it is present in almost all tax systems and is one of the most important issues not only of transition countries but also of more developed economies. Tax evasion is a world phenomenon. The problem is particularly acute in transition countries and developing countries, for those that do not have a well-developed revenue collection infrastructure (McGee, Tyler, 2006:1). Tax evasion limits a government's ability to raise revenues in order to meet budget requirements (Turner, 2010, p.28).

A universal definition of tax evasion and a unique attitude about the notion of the phenomenon itself does not exist, so the existence of more definitions creates a problem. Tax evasion is widely studied by Allingham, Sandmo (1972), Christie, Holzner (2006), Feld, Frey (2006), Richardson (2006), Cequeti, Coppier (2009), Russo (2010), Turner (2010), Alm
(2012), Pickhardt, Prinz, (2013) and many others. By researching tax evasion, we can notice various aspirations, circumstances and perspectives.

Economists tend to see (construct) tax evasion as a technical problem; social scientists (including psychologists) as a social problem (Kirchler, 2009, p.28). The relevance of social norms is generally supported by empirical studies on tax evasion (Kirchler, 2009, p.193). By its forms, tax evasion imposes greater material or financial damage than classical crime and can be a threat to macroeconomic stability. It does not cease to be the subject of daily political debate and if it comes to a deficit of a government budget, tax evasion becomes a more severe problem. Tax evasion is a very specific problem pervading different theoretical areas.

Tax evasion study implies a multidisciplinary approach to research, particularly from the point of view of taxpayer's behavior and a decision whether to comply with tax legislation. McGee, Basic and Tyler $(2009$, p.6) study whether tax evasion is considered ethical in Bosnia and Herzegovina. This study surveyed students at the University of Sarajevo in Bosnia and Herzegovina. The results indicate that the majority of respondents do not believe that tax evasion is ethical. The survey consisted of eighteen (18) statements. Using a seven-point Likert scale, respondents were asked to place the appropriate number in the space provided to indicate the extent of their agreement or disagreement with each statement (ibid, p.3). However, the ethical attitude toward tax evasion is more complicated than that.

Most of the respondents agreed with the strongest arguments justifying tax evasion occurs in cases where the government is perceived as being corrupt or when the tax system is seen as unfair or when tax funds are spent on projects that the respondent does not approve of (ibid, p.6). How much evasion really occurs nationally and locally? Do higher tax rates encourage/discourage compliance? How effective are penalty rates (Alm, 2012, p.26)? How to measure, explain, and control tax evasion (Alm, 2012, p.2)?

In this regard, this paper states that it is necessary to emphasize and intensify the research efforts, content-oriented and rounded up in scientific and professional publications, in the sphere of tax evasion as an essential component, gaining a better 
understanding of the role and effect of the subjective and objective factors influencing it.

The paper checks the main hypothesis by identifying the factors, both subjective and objective, that affect tax evasion and by determining their significance and impact, it is possible to construct a determination model with a view to preventing and reducing tax evasion. The auxiliary hypotheses of $\mathrm{H} 1$ are as follows, $\mathrm{H} 1 \mathrm{a}$ : Tax rate and tax fines have a substantial effect on tax evasion. $\mathrm{H} 1 \mathrm{~b}$ : Tax burden and the taxation system have a substantial effect on the amount of taxes evaded, H1c: Corruption has a substantial effect on tax evasion and $\mathrm{H} 1 \mathrm{~d}$ : Taxpayer morale and taxpayer culture have a substantial effect on the amount of taxes evaded by taxpayers.

The paper is organized as follows. Section 2 presents an analysis of subjective and objective factors of tax evasion. Section 3 overviews description of the sample and empirical data and presents research results on attitudes of respondents towards tax evasion in Bosnia and Herzegovina. Conclusion is given in Section 4.

\section{Analysis of subjective and objective factors of tax evasion: determinants identification}

There are many factors that influence and encourage tax evasion. Between individual factors there are interactions and they can present the structural problems of a country. There is a large number of factors on which the taxpayer has little or no influence as the factors change dynamically over time (economic conditions, business innovation, e-commerce development, economic crisis, political stability, resource availability, infrastructure, competitive situation, quality and ability of state institutions, tax legislation), and at the same time, they have a significant impact, and their stability is an essential precondition and most directly affects the financial situation of the taxpayer. In recent years discussions on this issue are even more intense, tax evasion is a controversial area that is difficult to harmonize, due to high complexity of all the factors.

It is well known that managing any phenomenon and concept requires knowledge of the determinants of that phenomenon and, of course, as one of the key issues, provides a starting point for formulating a policy to suppress this phenomenon. Subsequently, the question of what are the key determinants of tax evasion and which factors contribute to the gaps needs to be considered. Taxpayer dissatisfaction may arise from several sources: the perception of unfair treatment, the complexity and burden of the tax system, and the perception that the value of public goods and services received is less than taxes paid (exchange inequity) (Bloomquist, 2003, p4).

The main theoretical approaches to tax compliance have commonly been divided into the "economic deterrence" approach, and the wider behavioural approach which incorporates both social and fiscal psychological approaches. The economic deterrence model has been commonly used to examine tax evasion and compliance from a theoretical perspective (Jackson and Miliron, 1986). Factors that have been examined in the economic deterrence model include: complexity of the tax system, level of revenue information services, withholding and information reporting, prepared responsibilities and penalties, probability of receiving audit coverage, progressive and actual level of tax rates, and penalties for non-compliance (Devos, 2014, p.14).

The first major comprehensive overview of the taxpayer's behavior in tax evasion in the literature was given by Jackson and Milliron (1986, p.3 in general) providing the 14 most important tax evasion determinants. The determinants include: age, sex, education and occupation, status (demographic determinants), income level, income source, marginal tax rate, sanctions, fines and the possibility of disclosure (economic determinants) and complexity and fairness of the tax system, tax administration activity, ethics and tax morale (determinants of behavior). Allingham and Sandmo (1972) first established the theoretical basis for tax evasion research, based on the traditional economic model. They presented a theoretical model explaining what affects taxpayers to avoid paying tax liabilities. The model shows that a taxpayer will choose to avoid tax if the expected benefit is greater than the probability of detection and the level of punishment. Based on this model, the most practical strategy for increasing compliance with tax obligations is to create an increased risk of disclosure through controls and to
Terzić, S.

Model for determining subjective and objective factors of tax evasion 
Terzić, S.

Model for determining subjective and objective factors of tax evasion increase the level of punishment so that taxpayers take into account the risk of tax evasion. Tax evasion is influenced by multiple factors. They are by their very nature dynamic, fluid and extremely interdependent and therefore it is difficult to empirically analyze them. Factors affecting the fulfillment of tax obligations, or non-fulfillment, differ from country to country and also depend on individual behavior from one person to another (Kirchler, 2007). Factors affecting the behavior of a taxpayer can be business, industrial, sociological, economic and psychological (Khwaja et al., 2011, p.15, downloaded from the OECD 2004 b, Compliance Risk Management).

In the standard financial literature, the causes of tax evasion are commonly classified as: subjective factors and objective factors (Jovasevic, Gajic-Glamoclija, 2008, p.100).

The term subjective comes from the Latin word subiectus (subject) and the subjectivity derives from a personal taxpayer's mutual relationship. In economic relations, subjective factors are almost always present characteristic of human behavior, with an unpredictable function (Lovrić, Komić, Stević, 2017, p.383). The term objective comes from the Latin word obiectus (object), which means the object, what is placed in front.

Various researches indicate subjective (qualitative) or objective (quantitative) factors, and as the most often mentioned are the amount of tax burden, tax system, tax rate and penalties, corruption, inefficient tax administration organization, tax morale, attitudes of respondents according to tax regulations, social norms and national culture. Each of these factors has a different "weight or importance". Some factors that affect tax evasion may not yet be known, some, that are currently considered irrelevant, may have a different meaning in the future and some factors become important only through their interaction with other factors. The key choice that needs to be made after identifying the most important factors influencing tax evasion, for which it is possible to access the analysis and the knowledge, is to begin the resource routing process, focusing on improving it to minimize these dangers.

The tax system is the most effective and efficient instrument a country can have in collecting revenues. It plays an important role and it is the basis for the functioning of the state, but also the tax system has implications for the wider economic and social environment. According to Stiglitz (2004, p.464), five desirable characteristics of each tax system are: economic efficiency, administrative simplicity, flexibility, political responsibility and fairness. The tax system is an important part of the application of tax legislation and the existence of a large number of different taxation rules make the tax system complex. Tax legislation is the basis for taxation. Most people are either not interested or do not have a proper understanding of tax laws. They often have only a vague speculation about the taxes they pay. Poor understanding or misunderstanding provokes distrust and oppression (Kirchler, 2007, p.192).

The tax administration organization is an important determinant within each economic system, and it is an essential item in response to the challenges of tax evasion. Modern tax administrations exist and work on the principles of mutual compliance, keep up with the latest trends in taxation with a view to maximize value for the overall economy. Tax evasion is a very important and a long-lasting problem, which requires tax administration to improve business processes, methods and procedures in order to reduce the tax gap.

The tax evasion itself also depends on the willingness of the taxpayer to calculate the tax liabilities correctly and accurately and to pay them on time. The control system has an undeniable role and weakness of control over billing and the collection of public revenues by the tax administration is one of the causes of tax evasion. Voluntary tax payments depend greatly on whether taxpayers have a positive attitude towards the tax system, and especially whether they have the view that this is a fair system (Bloomquist, 2003, p.4).

The probability of detection and the level of punishment is one of the most important determinants of tax evasion. The willingness of taxpayers to engage in tax evasion is determined, among other things, by the probability of disclosure by the tax administration and the established level of penalties for tax evasion and fraud. In all highly developed societies, taxpayers know that tax evasion is banned and committing this criminal offense always carries with it the risk of disclosure and punishment. One of the determinants of tax evasion is the belief that 
the tax evasion attempt will be obstructed and punished (Aaron, Slemrod, 2004, p.90).

The question in focus of theoretical and empirical analysis of the effects of taxation is whether the existing tax burden and the tax rate are optimal and whether they affect tax evasion as well as whether their correction can more effectively achieve the targeted level of tax revenue. High tax burden and tax rates often imply different distortions in the taxpayer's economic behavior. Taxpayers feel tax relatively as a burden. Tax evasion increases if the tax burden or the tax base is higher, so in order for the state to compensate for lost revenues; it is required to increase the tax rate.

Likewise, political and legal security of a country affects economic development and can, therefore, be one of the parameters influencing evasion. Many countries today face the problem of corruption and despite the efforts to fight against it, it strongly influences tax evasion. There are many definitions of the concept of corruption. Jeremy Pope, former head of Transparency International, has defined corruption as "abuse of the entrusted authority for private gain" (Pope, 2000: 2). Corruption is an omnipresent phenomenon that occurs in all countries and represents a socially unacceptable and harmful phenomenon which, in addition to being in violation of positive legal regulations, directly threatens human rights, destroys morality, represents a deviation of basic social principles and endangers stability, efficiency and the economic progress of a country. Tax evasion and fiscal corruption have been widespread and persistent problem throughout history with serious economic consequences, not only in transition economies, but also in countries with developed tax systems (Cequeti, Coppier, 2009, p.1).

Morale, ethical behavior, ethical values and culture of behavior have an impact on tax evasion as well as degree and attitude towards compliance with tax regulations by taxpayers. Tax evasion may be avoided if the funds collected through taxation are consumed in order to meet the general social needs. Tax evasion factors also identify the social demographic characteristics of taxpayers, age, sex and education.

In that sense, the clarification of the key factors of tax evasion or the investigation that there are other factors that are equally or even more import- ant, de facto, confirm the complexity, significance and actuality of this problem. However, given all of the above-mentioned factors affecting tax evasion, researchers should note that most studies dealing with tax evasion, measuring the amount of tax evasion will probably be the subject of a system error, because there are prejudices about it, and therefore these questions are "treated with caution" (Alm, 2012, p.65). Finally, very little research has been done to date about the relationship between taxpayers and tax officials on questions of tax evasion and the factors they determine because most of the research so far focused on monitoring, researching and linking individual factors with tax evasion and the intent of this paper is to, by means of theoretical arguments, light up and point to possible directions of improvement in this area.

\section{Description of the sample and empirical data}

Dependent variable in this research is tax evasion (in the context of the level and extent of tax evasion), while independent variables would represent the tax system, the tax administration organization, the taxpayer's control, the tax burden and the tax rate, the likelihood of disclosure and punishment for tax evasion, the level of corruption.

Regression analysis will determine the form of interdependence (one dependent variable is explained by the influence of one or more independent variables), and by correlation analysis a verification of the significance and strength of dependencies of dependent and independent variables will be performed. Interdependence can be expressed as a favorable, disadvantageous or neutral relationship. Multiple regression analysis will be used when analyzing the data, possibly complementing the explorative factor analysis. Measuring the degree of correlation between dependent and independent variables will be performed by correlation analysis methods.

The main objective of this research is to identify key subjective and objective factors that influence tax evasion and determine the extent to which these factors influence the level of tax evasion in Bosnia and Herzegovina. In order to achieve the research goal, empirical analysis will focus on data collection both by taxpayers and tax administration
Terzić, S.

Model for determining subjective and objective factors of tax evasion 
Terzić, S.

Model for determining subjective and objective factors of tax evasion employees. In accordance with the subject and the problem of research and the aims of empirical research, in the sample two research groups or sub-groups have been investigated: 200 taxpayers (66.7\%) and 100 tax inspectors (33.3\%), whose attitudes, within further analysis and interpretation of data obtained by primary research, are comparable. Two groups of taxpayers are interviewed, by the nature of the "contradictory parties", the directors of companies or other responsible persons (Federation of Bosnia and Herzegovina, Republika Srpska and Brcko District of Bosnia and Herzegovina) who have intensive contacts with the tax administrations and employees in professional organizations (tax inspectors Indirect Taxation Authority BiH, tax inspectors Federation BiH, tax inspectors Republika Srpska and tax inspectors Brcko District BiH). For the purpose of conducting the research, a comprehensive, representative and appropriate questionnaire was produced, which constitutes a strong initiative for further investigation of the phenomenon of tax evasion.

\subsection{Analysis and presentation of research results on attitudes of respondents towards tax evasion}

Based on acquired theoretical and empirical findings on the characteristics of tax evasion, research has put subjective and objective factors of tax evasion at the center of discussion and explained that this relationship manifests in reality in depth and width, in the sense that the research included key factors. The quality of the regression model obtained is seen through the coefficient of determination or correlation coefficient. As the absolute value of this coefficient is closer to 1 , the model is better. The corrected coefficient of determination is interpreted, since it is done with the middle pattern.

In the context of auxiliary hypotheses, we define the following independent variables in the model:

H1a: Tax rates and fines - average of question 1.5 . (Fines/sanctions for tax evasion are disproportionate and inefficient and need to be far more severe) and question 1.1. Taxpayers who have not committed tax evasion are rare.

H1b: Tax burden and taxation system - average of question 3.11. (Tax burden rate), question 3.7. (Tax laws and rules are too complicated), question 5.3.
(Modification and improvement of tax regulations) and question 5.1. Improvement of control system and collection of taxes.

H1c: The corruption rate - the average of question 1.2. (People holding "high positions" do not abide to the norms in a society), 1.4. (Only people who are not directly responsible for the suppression of tax evasion are those who are talking negatively about it) and question 1.6. Tax evasion is, in most cases, unprovable.

H1d: Tax morale and culture - average of question 1.1. (Tax evasion represents the greatest brake of society development), question 1.3. (Tax evasion is equally present in all countries), question 1.7. (Tax evasion is one of the most important indicators of the collapse of system value), question 1.12. (Tax evasion is traditionally characteristic of our mentality), question 3.1. (By overall attitude of society to tax evasion), question 3.2. (By the level to which the public opinion on tax evasion has been developed), question 3.4. (Ethical Standards of Employees), question 3.9. (General culture about the need to pay taxes), question 5.2. Building moral norms on the need to pay taxes and questions 5.5 . Social benefits and security regulation.

By analyzing the rank correlation coefficient between the level of tax evasion variable as ordinal variable and variables of what is the attitude towards tax evasion, the satisfaction of respondents and the priorities in eliminating the obstacles for fighting against tax evasion (bolded correlation coefficients in Appendix 1) are obtained from statements that are statistically significant and positive. It is apparent from the enclosed data that, according to the level of the significant rank correlation coefficients, we can produce a ranking list of statements expressing the attitude towards tax evasion, satisfaction of respondents and priorities in eliminating the obstacles for fighting against tax evasion in the context of their impact on the level of tax evasion.

All rank correlation coefficients in the correlation matrix from Table 2 are statistically significant and positive, which justifies the creation of determination models with previously described dependent and independent variables.

The relation form, i.e. dependencies between the 
Table 1 Descriptive statistics for new variables (averages) that will represent independent variables in models

\begin{tabular}{|c|c|c|c|c|c|}
\hline & N & Minimum & Maximum & Average & Standard deviation \\
\hline Tax rate and fines & 300 & 1 & 5 & 3.578 & 0.776 \\
\hline Tax burden and taxation system & 300 & 1.5 & 5 & 3.313 & 0.701 \\
\hline The corruption rate & 300 & 1.33 & 5 & 3.191 & 0.669 \\
\hline Tax morale and culture & 300 & 1.9 & 5 & 3.045 & 0.473 \\
\hline
\end{tabular}

Source: the author.

Table 2 Correlation matrix for rank correlation coefficients between the level of tax evasion variable as ordinal variable and independent variables in models

\begin{tabular}{|c|c|c|}
\hline \multicolumn{1}{|c|}{ Spearman's rho } & Tax evasion rank \\
\hline \multirow{2}{*}{ Tax rate and fines } & Correlation coefficient & 0.344 \\
\hline \multirow{2}{*}{ Tax burden and taxation system } & Pvalue & 0.000 \\
\hline \multirow{2}{*}{ The corruption rate } & Correlation coefficient & 0.171 \\
\hline \multirow{2}{*}{ Tax morale and culture } & Pvalue & 0.003 \\
\hline & Correlation coefficient & 0.131 \\
\hline & Pvalue & 0.023 \\
\hline & Correlation coefficient & 0.151 \\
\hline
\end{tabular}

Source: the author.

Table 3 Multiple regression model with 4 independent variables

\begin{tabular}{|c|c|c|c|c|c|}
\hline & \multicolumn{2}{|c|}{ Non-standardized coefficients } & \multirow{2}{*}{$\begin{array}{c}\text { Standardized coefficients } \\
\text { Beta }\end{array}$} & \multirow[b]{2}{*}{$\mathrm{t}$} & \multirow{2}{*}{ Pvalue } \\
\hline & & Standard error & & & \\
\hline Free-standing article & -14.353 & 8.394 & & -1.71 & 0.088 \\
\hline Tax rate and fines & 6.949 & 1.526 & 0.265 & 4.553 & 0 \\
\hline $\begin{array}{c}\text { Tax burden and taxation } \\
\text { system }\end{array}$ & 3.042 & 1.721 & 0.105 & 1.767 & 0.078 \\
\hline The corruption rate & 0.046 & 1.859 & 0.002 & 0.025 & 0.98 \\
\hline Tax morale and culture & 5.432 & 2.739 & 0.126 & 1.983 & 0.048 \\
\hline
\end{tabular}

Source: the author.

observed variables are determined by a regression model, which, by means of mathematical formula and number of appropriate assumptions, in the best way describes quantitative dependence between variations of observed appearances in reality (Lovric and all, 2006, p. 357). If we take the rate of tax evasion, expressed as a breaking variable (middle interval), as a dependent variable and previously described four independent variables, to determine the mode of dependence between observed variables, we will evaluate the use of multiple regression model (Table 3).

According to the results from Table 3, by observing determined values the obtained model is significant. However, only two variables in the model are significant: the tax rate and fines and tax morale and culture ( $p$ values with $t$ test for independent variables are lower than 0,05 ). Therefore, in the following iteration we will eliminate independent variables that were not significant in the first model and will get another regression model whose parameters have been presented in Table 4 .

This model is also significant and both variables that are included are significant. Both independent variables are directly related to the level of tax evasion. This means that it is possible to present the model for determining the rate of tax evasion in the following way:

Level of tax evasion (middle interval) $=-10.215+$ 7.187 tax rate and fines (average H1a) + 7.153 tax morale and culture (average H1d)

Considering what is mentioned above, the following is confirmed by this model:

- The first auxiliary hypothesis with the main hypothesis: H1a: Tax rate and fines have a
Terzić, S.

Model for determining subjective and objective factors of tax evasion 
Terzić, S.

Model for determining subjective and objective factors of tax evasion

Table 4 Multiple regression model with 2 independent variables

\begin{tabular}{|c|c|c|c|c|c|}
\hline & \multicolumn{2}{|c|}{ Non-standardized coefficients } & \multirow{2}{*}{$\begin{array}{c}\text { Standardized coefficients } \\
\text { Beta }\end{array}$} & \multirow{2}{*}{$\mathrm{t}$} & \multirow{2}{*}{ Pvalue } \\
\hline & $\mathrm{b}$ & Standard error & & & \\
\hline Free-standing article & -10.215 & 7.899 & & -1.293 & 0.197 \\
\hline Tax rate and fines & 7.187 & 1.478 & 0.274 & 4.864 & 0 \\
\hline Tax morale and culture & 7.153 & 2.423 & 0.166 & 2.952 & 0.003 \\
\hline
\end{tabular}

Source: the author.

significant effect to tax evasion and the fourth auxiliary hypothesis with the main hypothesis: Tax morale and culture have a significant effect to the level of tax evasion of taxpayers.

- The second ( $\mathrm{H} 1 \mathrm{~b}$ : Tax burden and taxation system have significant influence to the level of tax evasion) and the third (H1c: Corruption rate has significant effect to tax evasion) auxiliary hypothesis with the main hypothesis are not confirmed by this model.

If we take the level of tax evasion, expressed as a breaking variable (middle interval), as a dependent variable and if we include variables that are expressing an attitude towards tax evasion as independent variable, the satisfaction of respondents and priorities in removing the obstacles for fighting against tax evasion, and in accordance to the rank correlation coefficient that had a significant relation to the level of tax evasion, we will evaluate the multiple regression model.

According to the results from the previous table, the obtained model is significant. However, only three

Table 5 Multiple regression model with 11 independent variables

\begin{tabular}{|c|c|c|c|c|c|}
\hline & Non-stanc & dized coefficients & $\begin{array}{l}\text { Standardized } \\
\text { coefficients }\end{array}$ & $t$ & Pvalue \\
\hline & $b$ & Standard error & Beta & & \\
\hline Free-standing article & -13.931 & 8.272 & & -1.684 & 0.093 \\
\hline $\begin{array}{l}\text { 1.1. Tax evasion makes the biggest } \\
\text { break in the development of a society }\end{array}$ & 3.197 & 1.14 & 0.167 & 2.804 & 0.005 \\
\hline $\begin{array}{l}\text { 1.2. Persons holding "high positions" do } \\
\text { not abide to the norms of a society }\end{array}$ & -0.518 & 1.219 & -0.025 & -0.425 & 0.671 \\
\hline $\begin{array}{l}\text { 1.4. Only people who are not directly } \\
\text { responsible for the suppression of } \\
\text { tax evasion are those who are talking } \\
\text { negatively about it }\end{array}$ & 1.029 & 1.113 & 0.053 & 0.925 & 0.356 \\
\hline $\begin{array}{l}\text { 1.5. Fines/sanctions for tax evasion are } \\
\text { disproportionate and ineffective and } \\
\text { they should be far more severe }\end{array}$ & 2.632 & 1.19 & 0.13 & 2.211 & 0.028 \\
\hline $\begin{array}{l}\text { 1.7. Tax evasion is one of the most } \\
\text { important indicators of the collapse of } \\
\text { system value }\end{array}$ & -0.16 & 1.394 & -0.007 & -0.115 & 0.908 \\
\hline $\begin{array}{l}\text { 1.11. Taxpayers who have not commit- } \\
\text { ted tax evasion are rare }\end{array}$ & 3.189 & 1.106 & 0.168 & 2.885 & 0.004 \\
\hline $\begin{array}{l}\text { 5.1. Improvement of the control system } \\
\text { and tax collection }\end{array}$ & 1.71 & 1.223 & 0.082 & 1.398 & 0.163 \\
\hline $\begin{array}{l}\text { 5.3. Modification and improvement of } \\
\text { tax regulations }\end{array}$ & 1.199 & 1.318 & 0.058 & 0.91 & 0.364 \\
\hline $\begin{array}{l}\text { 5.4. Improvement of economic working } \\
\text { conditions }\end{array}$ & 0.704 & 1.395 & 0.035 & 0.505 & 0.614 \\
\hline $\begin{array}{l}\text { 5.5. Social benefits and security } \\
\text { regulation }\end{array}$ & -0.07 & 1.389 & -0.003 & -0.05 & 0.96 \\
\hline 5.6. Regulation of the informal sector & 1.771 & 1.308 & 0.086 & 1.354 & 0.177 \\
\hline
\end{tabular}

Source: the author. 
Table 6 Multiple regression model with 3 independent variables

\begin{tabular}{|c|c|c|c|c|c|}
\hline & Non-stant & lized coefficients & $\begin{array}{l}\text { Standardized } \\
\text { coefficients }\end{array}$ & t & Pvalue \\
\hline & b & Standard error & Beta & & \\
\hline Free-standing article & -0.543 & 5.759 & & -0.094 & 0.925 \\
\hline $\begin{array}{l}\text { 1.1. Tax evasion makes the biggest break } \\
\text { in the development of a society }\end{array}$ & 3.555 & 1.085 & 0.186 & 3.278 & 0.001 \\
\hline $\begin{array}{l}\text { 1.5. Fines/sanctions for tax evasion are } \\
\text { disproportionate and ineffective and } \\
\text { they should be far more severe }\end{array}$ & 3.173 & 1.139 & 0.157 & 2.785 & 0.006 \\
\hline $\begin{array}{l}\text { 1.11. Taxpayers who have not commit- } \\
\text { ted tax evasion are rare }\end{array}$ & 3.8 & 1.045 & 0.2 & 3.637 & 0 \\
\hline
\end{tabular}

Source: the author.

independent variables in the model are significant ( $p$ values with $t$ test for independent variables are lower than 0.05). Therefore, in the following iteration we will eliminate independent variables that were not significant in the first model and will get another regression model.

This model is also significant and all variables that are included are significant. All three independent variables are directly related to the level of tax evasion. This means that it is possible to present the model for determining the rate of tax evasion in the following way:

Level of tax evasion (middle interval) $=-0.543+$ 3.555 evaluation Tax evasion makes the biggest break in the development of a society +3.173 evaluation Fines/sanctions for tax evasion are disproportional and ineffective and they should be far more severe +3.8 evaluation Taxpayers who have not committed tax evasion are rare.

Both variables are included in the last model in accordance with hypothesis $\mathrm{H} 1 \mathrm{a}$ and one variable from hypothesis H1d. So, with this model:

- The first auxiliary hypothesis with the main hypothesis has been confirmed: H1a: Tax rate and fines have a significant effect on tax evasion

- The fourth auxiliary hypothesis with the main hypothesis has been partly confirmed: H1d: Tax morale and culture have a significant effect on the level of tax evasion of taxpayers.

\section{Conclusion}

Though it is understood that tax evasion is a very important and complex phenomenon and that it is a major obstacle to economic growth and development, the factors, trends, prevalence and effects of tax evasion are examined as mere exceptions. Such research is rare in Bosnia and Herzegovina, insufficiently complex, it covers a small number of aspects of the phenomenon and provides merely a screenshot of the situation, with no longitudinal analysis of trends in the practice of taxpayers and tax authorities. The research conducted in this paper has presented the entire analysis of the tax evasion problem in Bosnia and Herzegovina, and has shown "hot spots" and the key objective and subjective tax evasion factors (since the analysis creates the basis for quality and critical view of the content). The intention was also to point out the significance of certain factors necessary for understanding the question of tax evasion. Analysis of the research results may lead to different conclusions, given that analytical perception contains various approaches but still the intention is the consistent and objective assessment. Through this research it may be concluded that the factors of tax rate, penalties, tax morale and taxpayer culture have a major effect on tax evasion. Tightening up on the penal policy would contribute to the suppression and more efficient fight against all types of tax evasion. Increasing tax morale and taxpayer culture should contribute to enhancing tax compliance of taxpayers on the one hand and the tax authorities should, on the other hand, use their measures to enhance morale and taxpayer culture. The work certainly did not provide an answer to all questions related to tax evasion, but it is a good attempt to study the tax evasion factors from different aspects and to identi-
Terzić, S.

Model for determining subjective and objective factors of tax evasion 
Terzić,S.

Model for determining subjective and objective factors of tax evasion fy solutions through the appropriate model in terms of the level of tax evasion reduction. The proposed model of determination justifies further research with the aim of defining a more complex model, which would involve a larger number of tax evasion factors. In Bosnia and Herzegovina, no studies have been conducted to date on subjective and objective factors of tax evasion in this way or in such a degree, and this work is an attempt to analyze tax evasion from an unexplored side, and, in particular, with regard to that, the proposed models may cre- ate conditions for improving the current situation by establishing a modern approach to tackling tax evasion for fiscal authorities in Bosnia and Herzegovina. The key advantage of this research is the fact that in the future it will be possible to compare data and see what trends are to be expected in a given time period. We now know a lot more about tax evasion and compliance but, we are far from knowing it all. Further research is required (Pickhardt, Prinz, 2013, p.14).

\section{Literature}

Aaron, H., Slemrod, J. (2004) The Crisis in Tax Administrations. Washingotn: The Brookings Institution.

Allingham, M. G., Sandmo, A. (1972) Income Tax Evasion: A Theoretical Analysis. Journal of Public Economic, 1: 323-338.

Alm, J. (2011) Measuring, explaining, and controlling tax evasion: lessons from theory, experiments, and field studies. Springer Science+Business Media, LLC 2011.

Alm, J. (2012) Measuring, Explaining, and Controlling Tax Evasion: Lessons from Theory, Experiments, and Field Studies, Working Paper 1213, Tulane University, 1-33.

Bloomquist, M. K. (2003) Tax Evasion, Income Inequality and Opportunity Costs of Compliance, Paper presented at the 96th Annual Conference of the National Tax Association, Chicago: 1-26.

Cequeti, R., Coppier, R. (2009) Economic growth, corruption and tax evasion. Quaderno di Dipartimento, 58: $1-22$.

Christie, E., Holzner, M. (2006) What Explains Tax Evasion? An Empirical Assessment Based on European Data, The Vienna Institute for International Economic Studies, Working Papers 40.

Devos, K. (2014) Factors Influencing Individual Taxpayer Compliance Behaviour. Springer Science+Business Media Dordrecht.

Feld, L. P., Frey, B. S. (2002) Deterrence and Tax Morale: How Tax Administration and Taxpayers Interact, www.oecd.org/tax/administration [22.8. 2015.].

Jackson, B. R., Milliron, V. C. (1986) Tax compliance research: Findings, problems and prospects. Journal of Accounting, 5: 125-165.

Jelcic, B. (2001) Public Finances. Zagreb: RRiF.

Jovasevic, D., Gajic-Glamoclija, M. (2008) Tax evasion - manifestation forms and suppression measures, Beosing, Belgrade.

Khwaja, M., Awasthi, R., Loeprick, J. (2011) Risk-Based Tax Audits, Approaches and Country Experinces. Washington: World Bank.

Kirchler, E. (2007) The Economic Psychology of Tax Behaviour. Cambridge University Press. 
Kirchler, E. (2009) The Economic Psychology of Tax Behaviour. Cambridge University Press.

Lovric, M., Komic, J., Stevic, S. (2017) Statistical analysis, Methods and implementation, 2nd edition, Banja Luka, National and University library of Republica of Srpska.

McGee, R., Basić, M., Tyler, M. (2009) Tax evasion in Bosnia. Journal of Balkan and Near Eastern Studies.

McGee, W. R., Tyler, M. (2006) Tax Evasion and Ethics: A Demographic Study of 33 Countries, Andreas School of Business Working Paper, Barry University, Miami: 1-20.

Pickhardt, M., Prinz,A. (2013) Behavioral dynamics of tax evasion - A survey. Journal of Economic Psychology, Article in Press, 1-19.

Pope, J. (2000) Confronting Corruption: The Elements of a National Integrity System (TI Source Book). Berlin: TI.

Richardson, G. (2006) Determinants of tax evasion: A cross-country investigation. Journal of International Accounting, Auditing and Taxation, 15: 150-169.

Rovcanin, A. (2006) Finance management. Sarajevo: Faculty of Economics Sarajevo.

Russo, F. F. (2010) Tax Evasion and Community Effects in Italy. CSEF Centre for Studies in Economics and Finance Working paper no. 254.

Stiglitz, J. (2004) Public sector economy. First edition, Publishing Center of the Faculty of Economics in Belgrade.

Turner, C. S. (2010) Essays in Crime and Tax Evasion, Economics Dissertation Paper 64,1-163, Retrieved from http://digitalarchive.gsu.edu/econ_diss/64 [01.07.2015].

Vujaklija, M. (1991) Lexicon of foreign words and expressions. Beograd: Prosveta. 
Terzić, S.

Model for determining subjective and objective factors of tax evasion

\section{Appendix}

Appendix 1 Correlation matrix for rank correlation coefficients between the level of tax evasion variable as an ordinal variable and variables that are expressing the attitude towards tax evasion, the satisfaction of respondents and priorities in removing obstacles for fighting against tax evasion

\begin{tabular}{|c|c|c|}
\hline \multicolumn{2}{|l|}{ Spearman's rho } & Tax evasion rank \\
\hline \multirow{2}{*}{$\begin{array}{l}\text { 1.1. Tax evasion is the largest break in the development of } \\
\text { a society }\end{array}$} & Correlation coefficient & 0.286 \\
\hline & $P$ value & 0 \\
\hline \multirow{2}{*}{$\begin{array}{l}\text { 1.2. People holding "high positions" do not abide to the } \\
\text { norms in a society }\end{array}$} & Correlation coefficient & 0.161 \\
\hline & $P$ value & 0.005 \\
\hline \multirow{2}{*}{ 1.3. Tax evasion is equally present in all countries } & Correlation coefficient & 0.066 \\
\hline & $P$ value & 0.252 \\
\hline \multirow{2}{*}{$\begin{array}{l}\text { 1.4. Only people who are not directly responsible for the } \\
\text { suppression of tax evasion are those who are talking } \\
\text { negatively about it }\end{array}$} & Correlation coefficient & 0.126 \\
\hline & $P$ value & 0.029 \\
\hline \multirow{2}{*}{$\begin{array}{l}\text { 1.5. Fines/sanctions for tax evasion are disproportionate and } \\
\text { ineffective and they should be far more severe }\end{array}$} & Correlation coefficient & 0.245 \\
\hline & Pvalue & 0 \\
\hline \multirow{2}{*}{ 1.6. Tax evasion is, in most cases, unprovable } & Correlation coefficient & -0.007 \\
\hline & Pvalue & 0.898 \\
\hline \multirow{2}{*}{$\begin{array}{l}\text { 1.7. Tax evasion is one of the most important indicators of the } \\
\text { collapse of system value }\end{array}$} & Correlation coefficient & 0.131 \\
\hline & $P$ value & 0.023 \\
\hline \multirow{2}{*}{$\begin{array}{l}\text { 1.8. Low level of personal income affects the level of tax } \\
\text { evasion }\end{array}$} & Correlation coefficient & -0.021 \\
\hline & Pvalue & 0.722 \\
\hline \multirow{2}{*}{$\begin{array}{l}\text { 1.9. Tax evasion is a common occurrence for countries in } \\
\text { transition }\end{array}$} & Correlation coefficient & -0.044 \\
\hline & Pvalue & 0.447 \\
\hline \multirow{2}{*}{$\begin{array}{l}\text { 1.10. Media exaggerate when pointing out to harmful effects } \\
\text { of tax evasion }\end{array}$} & Correlation coefficient & -0.064 \\
\hline & P value & 0.271 \\
\hline \multirow{2}{*}{ 1.11. Taxpayers who have not committed tax evasion are rare } & Correlation coefficient & 0.27 \\
\hline & Pvalue & 0 \\
\hline \multirow{2}{*}{$\begin{array}{l}\text { 1.12. Tax evasion is traditionally characteristic of our } \\
\text { mentality }\end{array}$} & Correlation coefficient & 0.093 \\
\hline & Pvalue & 0.107 \\
\hline \multirow{2}{*}{ 1.13. Poor education is the reason for tax evasion } & Correlation coefficient & -0.006 \\
\hline & Pvalue & 0.922 \\
\hline \multirow{2}{*}{ 3.1. By overall attitude of society to tax evasion } & Correlation coefficient & -0.002 \\
\hline & Pvalue & 0.973 \\
\hline \multirow{4}{*}{$\begin{array}{l}\text { 3.2. By the level to which the public opinion on tax evasion } \\
\text { has been developed } \\
\text { 3.3. By work and organisation od tax administrations (UINO } \\
\text { - Indirect taxation authority; PU RS - Tax administration of } \\
\text { RS; PU FBIH - Tax administration of FBIH; PU BDBIH - Tax } \\
\text { administration of Brcko district BIH) }\end{array}$} & Correlation coefficient & -0.005 \\
\hline & Pvalue & 0.93 \\
\hline & Correlation coefficient & -0.083 \\
\hline & P value & 0.15 \\
\hline \multirow{2}{*}{ 3.4. By ethical standards of employees } & Correlation coefficient & 0.026 \\
\hline & $P$ value & 0.659 \\
\hline \multirow{2}{*}{$\begin{array}{l}\text { 3.5. By possibility of obtaining information on the work of } \\
\text { responsible persons }\end{array}$} & Correlation coefficient & -0.06 \\
\hline & $P$ value & 0.298 \\
\hline \multirow{2}{*}{ 3.6. By own professional developoment } & Correlation coefficient & -0.019 \\
\hline & $P$ value & 0.748 \\
\hline \multirow{2}{*}{ 3.7. Tax laws are too complicated } & Correlation coefficient & 0.019 \\
\hline & $P$ value & 0.742 \\
\hline \multirow{2}{*}{$\begin{array}{l}\text { 3.8. By general economic situation and terms to provide the } \\
\text { existence by work }\end{array}$} & Correlation coefficient & -0.032 \\
\hline & P value & 0.583 \\
\hline \multirow{2}{*}{ 3.9. By general culture of need to pay taxes } & Correlation coefficient & -0.025 \\
\hline & P value & 0.663 \\
\hline \multirow{2}{*}{ 3.10. Collected taxes are being irrationally used by a state } & Correlation coefficient & -0.09 \\
\hline & P value & 0.12 \\
\hline ten level & Correlation coefficient & 0.083 \\
\hline 3.11. lax burden level & $P$ value & 0.152 \\
\hline
\end{tabular}




\begin{tabular}{|l|c|c|}
\hline \multicolumn{1}{|c|}{ Spearman's rho } & Tax evasion rank \\
\hline 5.1. Improvement of control system and tax collection & Correlation coefficient & 0.181 \\
\hline 5.2. Building up the moral standards of the need to pay taxes & Correlation coefficient & 0.002 \\
\hline 5.3. Modification and improvement of tax regulations & Pvalue & 0.108 \\
\hline 5.4. Improvement of economic working conditions & Correlation coefficient & 0.061 \\
\hline 5.5. Social benefits and security regulation & Correlation coefficient & 0.189 \\
\hline 5.6. Regulation of the informal sector & Pvalue & 0.001 \\
\hline
\end{tabular}

Source: the author. 
